\title{
Agroclimatic aptitude for peanut in the West region of the state of Mato Grosso
}

\section{Aptidão agroclimática para o amendoim na região oeste do Estado do Mato Grosso}

\author{
João Danilo BARBIERI ${ }^{1}$; Rivanildo DALLACORT ${ }^{2}$; Henrique da Cruz RAMOS ${ }^{3}$; Marco Antônio Camillo \\ de CARVALHO ${ }^{4}$; Alcir José MODOLO5 ${ }^{5}$ Adalberto SANTI ${ }^{6}$; Kassio de MARCO ${ }^{7}$ \\ ${ }^{1}$ Autor para correspondência Mestrando em Ambiente e Sistema de Produção Agrícola; Universidade do Estado de \\ Mato Grosso - UNEMAT - Departamento de Agronomia - joaodanilobarbieri@hotmail.com \\ ${ }^{2}$ Professor da Pós-graduação em Ambiente e Sistema de Produção Agrícola, Universidade do Estado de Mato Grosso - \\ UNEMAT - rivanildo@unemat.br \\ ${ }^{3}$ Mestre em Ambientes de Sistema Agrícola Universidade do Estado de Mato Grosso - UNEMAT \\ henriquecruzr@hotmail.com \\ ${ }^{4}$ Professor da Pós-graduação em Ambiente e Sistema de Produção Agrícola, Universidade do Estado de Mato Grosso - \\ UNEMAT - marcocarvalho@unemat.br \\ ${ }^{5}$ Professor Doutor em agronomia, Universidade Tecnológica Federal do Paraná - UTFPR - alcir@utfpr.edu.br \\ ${ }^{6}$ Professor Mestre em agronomia, Universidade do Estado de Mato Grosso - UNEMAT - adalbertosanti@unemat.br \\ ${ }^{7}$ Engenheiro agrônomo, Universidade do Estado de Mato Grosso - UNEMAT - kassio.marco@hotmail.com
}

Recebido em: 11-02-2014; Aceito em: 21-07-2016

\begin{abstract}
Peanut crop (Arachis hypogea L.) has great food interest due to its high content of protein and oil, however, there is the need to observe its aptitude for a certain region where temperature and rainfall data provided by Instituto Nacional de Meteorologia (INMET) were used from 1961 to 2012. The production of peanut crop is highly influenced by weather conditions as well as all crops, thus this study aims at determining agroclimatic aptitude of the peanut crop in the municipalities of Campo Novo do Parecis, Cuiabá, Cáceres, Diamantino, São José do Rio Claro and Tangará da Serra all located at the state of Mato Grosso. The means of meteorological elements were ten-day calculated, totaling 36 ten-day periods for each climate variable and municipality. Based on the analysis of climate variables together to hydro and thermal crop requirements ranging from 500 to 700 $\mathrm{mm}$ and between 22 and $28 \mathrm{C}$, respectively, it is concluded that peanut crop is considered suitable for the conditions found in the regions, considering that the thermal requirement of all ten-day periods were within or close to the ideal range of development. Rainfall is suitable by peanut crop from $13^{\text {th }}$ to $26^{\text {th }}$ of ten-days.
\end{abstract}

Additional keywords: (Arachis hypogea L.); climatic conditions; ten-day period.

\section{Resumo}

A cultura do amendoim (Arachis hypogea L.) possui grande interesse alimentar devido ao seu alto teor de proteína e óleo; para tanto, tem-se a necessidade de observar sua aptidão para determinada região, onde, neste trabalho, foram utilizados dados de temperatura e precipitação disponibilizados pelo Instituto Nacional de Meteorologia (INMET), no período de 1961 a 2012. A produção da cultura do amendoim é altamente influenciada pelas condições climáticas, assim como todas as culturas; portanto, este estudo visa a determinar a aptidão agroclimática nos municípios de Campo Novo do Parecis, Cuiabá, Cáceres, Diamantino, São José do Rio Claro e Tangará da Serra, todos pertencentes ao Estado de Mato Grosso. As médias dos elementos meteorológicos foram calculadas de forma decendial, totalizando 36 decêndios para cada variável climática e municípios. Com base nas análises das variáveis climáticas, conjuntamente às necessidades hídricas e térmicas da cultura que variam de 500 a $700 \mathrm{~mm}$ e entre 22 a $28^{\circ} \mathrm{C}$, respectivamente, conclui-se que o cultivo de amendoim é considerado apto para as condições encontradas nas regiões, considerando que as necessidades térmicas da cultura, em todos os decêndios, apresentaram-se dentro ou próximas da faixa ideal de desenvolvimento. A precipitação encontra-se tolerável pela cultura do 13 o ao 26 o decêndio.

Palavras-chave adicionais: (Arachis hypogea L.); condições climáticas; decêndio.

\section{Introduction}

Peanut (Arachis hypogea L.) is a species from fabaceae family characterized as one of the most important crop for human consumption due to its oil production characteristics (40 to $45 \%$ ) and protein (20 to $28 \%$ ) (Monteiro, 2007; Silveira, 2010). In addition to fresh consumption, its oil can directly be used in food and in the paint, preserves and pharmaceuticals industries beyond its potential for biodiesel production (Godoy et al., 2005).

The peanut world production is in the range of 33.2 million tons of grain, $30 \%$ of this production is 
intended for human consumption, both in natura and industrialized and the remaining $70 \%$ as edible oil.

In production terms, the production of Brazilian peanut comes from Southeast, on larger scale, followed by the Midwest and Northeast Brazil (Embrapa, 2006). The peanut is cultivated in more than 80 countries of two hemispheres, mainly in tropical regions in the range of latitude $30^{\circ} \mathrm{N}$ and $\mathrm{S}$. Despite of this wide adaptability, productivity is strongly influenced by environmental factors, especially air temperature, water availability and solar radiation (Peixoto et al., 2008).

Adverse environmental conditions reduce differently plant growth depending on its stage vegetative or reproductive (Santos et al., 2006). It can also change the cycle duration that ranges from 90 to 115 days for earlier cultivars and 120 to 140 days for late cultivars (Reichardt, 1987; Doorenbos \& Kassam, 1994).

In studies Silva \& Amaral (2008) state that crop allows a wide range of cultivation, from equatorial to temperate climates and a hot and humid season is needed, enough to allow plant vegetation, however it is very resistant to drought, favored by development of its root system to great depths allowing greater exploitation of soil moisture, on the other hand, culture is not suitable for areas with very prolonged humid season, because it favors the attack of fungi and incidence of diseases, in addition harming harvest and product quality.

According to Cunha \& Assad (2001), climatic factors are the main cause of fluctuations on the productivity of grains because temperature and rainfall, for example, cannot be controlled or modified by man on a large scale. Thus this study aims at determining the peanut crop aptitude for Campo Novo do Parecis, Cáceres, Cuiabá, Diamantino, São José do Rio Claro, and Tangará da Serra - MT, observing the ten-day climatic conditions of rainfall and air temperature determining one or more appropriate period to this plant cultivation.

\section{Material and methods}

The study was conducted in CPEDA - Centro de Pesquisas, Estudos e Desenvolvimento Agroambientais in the laboratory of Agrometeorology of Universidade do Estado de Mato Grosso UNEMAT, Tangará da Serra Campus, rainfall and air temperature data recorded at weather stations from Instituto Nacional de Meteorologia (INMET) were used. After data acquisition, and analysis of the consistency and gap filling was performed using CLIMATE software (Faria et al., 2003), developed by the Instituto Agronômico do Paraná (IAPAR), for the municipalities under study (Table 1).

Data were analyzed and compared to water requirements described by Sarr et al. (2004) and thermal by Nogueira \& Távora (2005). Based on these requirements and considering the average crop cycle of 110 days, evaluations were carried out in ten-day periods totaling 11 periods of ten-days to complete its cycle.

Table 1 - Location of weather stations used in determining peanut crop agroclimatic aptitude.

\begin{tabular}{cllllc}
\hline Classification & \multicolumn{1}{c}{ Reference } & Latitude & Longitude & Altitude & Period \\
\hline Aw & Campo Novo do Parecis & $13^{\circ} 38^{\prime} \mathrm{S}$ & $58^{\circ} 17^{\prime} \mathrm{W}$ & $596.0 \mathrm{~m}$ & 2003 a 2012 \\
Aw & Cáceres & $16^{\circ} 03^{\prime} \mathrm{S}$ & $57^{\circ} 41^{\prime} \mathrm{W}$ & $118.0 \mathrm{~m}$ & 1961 a 2012 \\
$\mathrm{Aw}$ & Cuiabá & $15^{\circ} 33^{\prime} \mathrm{S}$ & $57^{\circ} 07^{\prime} \mathrm{W}$ & $151.3 \mathrm{~m}$ & 1961 a 2012 \\
Aw & Diamantino & $14^{\circ} 24^{\prime} \mathrm{S}$ & $56^{\circ} 27^{\prime} \mathrm{W}$ & $286.3 \mathrm{~m}$ & 1961 a 2012 \\
Aw & São José do Rio Claro & $13^{\circ} 25^{\prime} \mathrm{S}$ & $56^{\circ} 42^{\prime} \mathrm{W}$ & $350.0 \mathrm{~m}$ & 1996 a 2012 \\
$\mathrm{Aw}$ & Tangará da Serra & $14^{\circ} 39^{\prime} \mathrm{S}$ & $57^{\circ} 25^{\prime} \mathrm{W}$ & $321.5 \mathrm{~m}$ & 2003 a 2012 \\
\hline
\end{tabular}

Thus, areas were considered suitable for cultivation when the rainfall during the cycle, accounted between 500 and $700 \mathrm{~mm}$ and the average air temperature were between 22 and $28^{\circ} \mathrm{C}$. It is restricted when rainfall throughout cycle is greater than $700 \mathrm{~mm}$ and average air temperature during the 12 ten-day period is less than $22^{\circ} \mathrm{C}$ or higher than $28^{\circ} \mathrm{C}$. The region that present rainfall below $500 \mathrm{~mm}$ and average air temperature lower $18^{\circ} \mathrm{C}$ or greater than $33^{\circ} \mathrm{C}$ is inapt, as proposed Assunção \& Escobedo (2009).

\section{Results and discussions}

The municipality of Diamantino had the highest annual rainfall, with $1806.6 \mathrm{~mm}$; the lowest occurred in Cuiabá with $1493.5 \mathrm{~mm}$ (Figure 1). For all stations, annual historical averages exceeded $1400 \mathrm{~mm}$ distributed from October to March characterized as rainy season (Dallacort et al., 2011), and level considered suitable for cultivation of peanuts. The same variation was observed by Cardozo et al. (2010) in a study conducted in the state of São Paulo.

The annual average temperature (Figure 2) ranged from $24,6^{\circ} \mathrm{C}$ in the municipality of Campo Novo do Parecis to $26.8^{\circ} \mathrm{C}$ in Cuiabá. Assunção \& Escobedo (2009) proposed that the optimal range for crop development is between 22 to $28^{\circ} \mathrm{C}$, thus, the annual average air temperature is in the optimum range for all regions considered. 


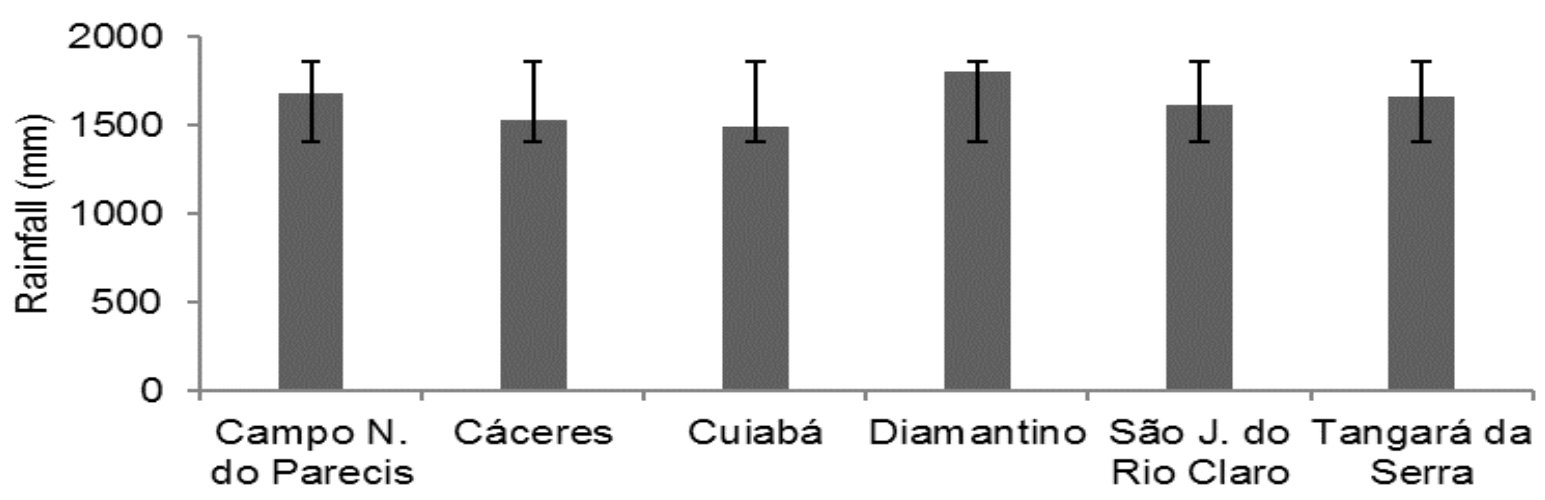

Municipalities

Figure 1 - Average annual rainfall and standard deviation in the municipalities of Middle North of Mato Grosso.

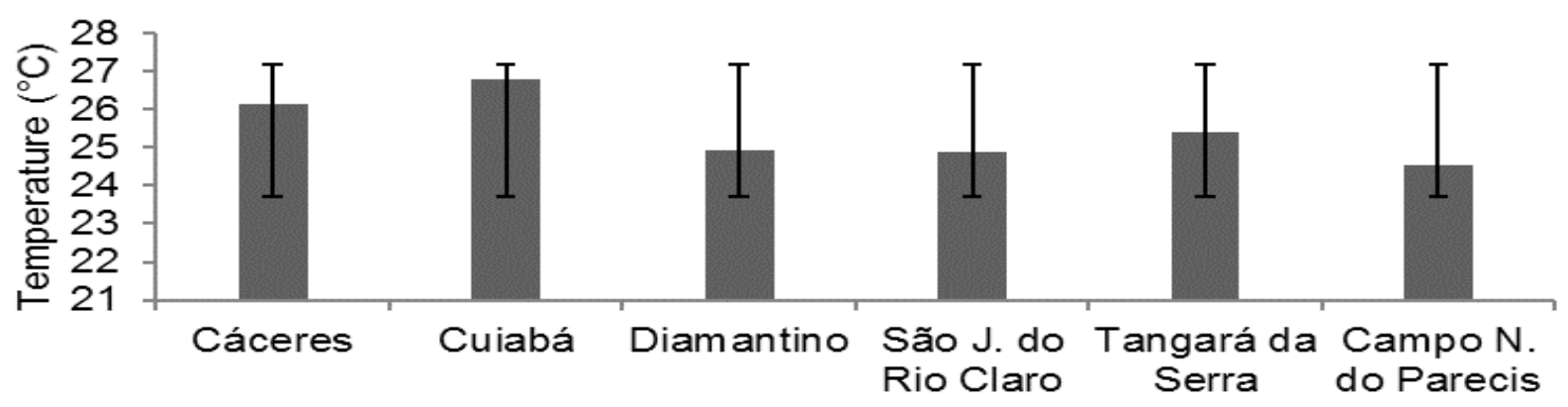

Municipalities

Figure 2 - Annual average temperature and standard deviation of the average in the municipalities of Middle North of Mato Grosso.

The ten-day distribution of rainfall and variations of average high, low and medium temperatures for the municipalities of Campo Novo do Parecis; Cáceres; Cuiabá; Diamantino; São José do Rio Claro and Tangará da Serra, indicate that regions have similar characteristics regarding rainfall distribution and variation in air temperature. By observing a rainy season from October to March with high temperatures and a dry period from April to September with mild temperatures, which according to Sousa (1998) is a characteristic pattern of cerrado region.
For the municipality of Campo Novo do Parecis is observed that the highest rainfall levels were recorded in periods of ten days 2; $3 ; 4$ and 5 which respectively show 100.94; 109.87; 97.96 and $104.04 \mathrm{~mm}$. The less rainy period is from 13-27 periods of ten-day ranging from 5 to $18 \mathrm{~mm}$. The annual historical average rainfall for the municipality is $1682.33 \mathrm{~mm}$. For temperature factor the annual average is $24.5^{\circ} \mathrm{C}$, with higher averages found in periods of ten-day 21-28 reaching $34.2^{\circ} \mathrm{C}$ and lower average found in periods of ten-day $13-19$ reaching $14.9^{\circ} \mathrm{C}$ (Figures 3, 4, 5, 6, 7, 8).

\section{Campo N. Parecis}

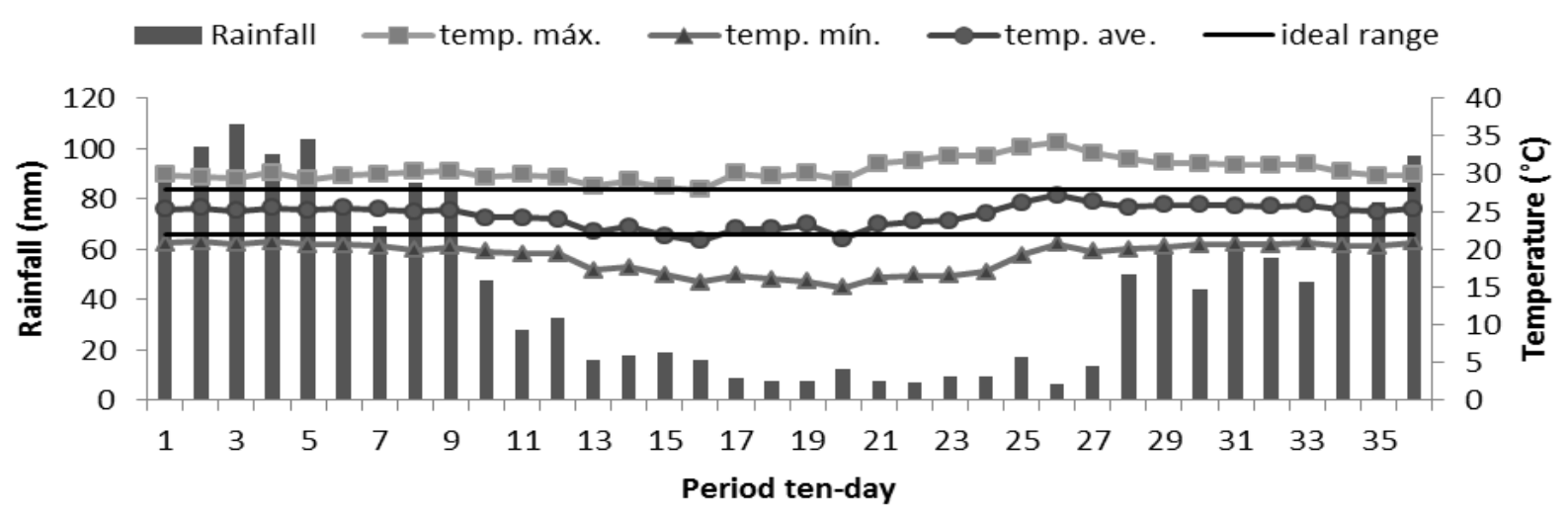

Figure 3 -Ten-day period rainfall distribution and average (ave.) maximum (máx) and minimum (mín.) temperatures (temp.) in the municipality of Campo Novo Parecis - MT. 


\section{Cáceres}

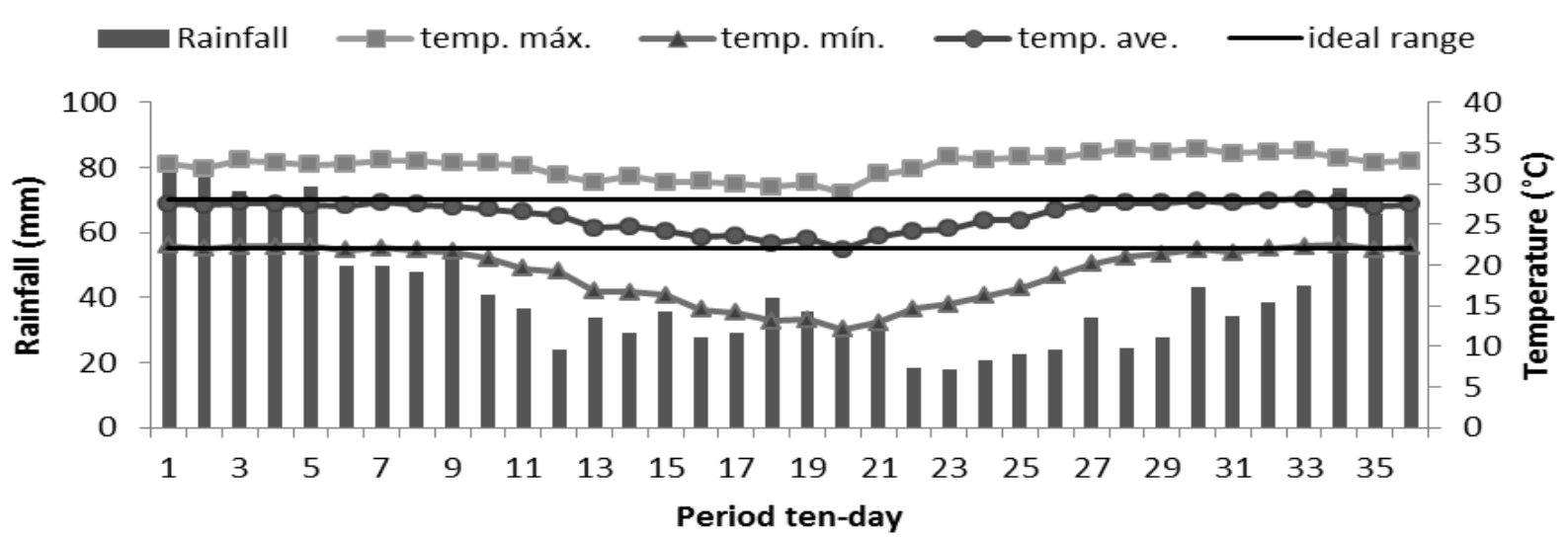

Figure 4 - Ten-day period rainfall distribution and average (ave.) maximum (máx.) and minimum (mín.) temperatures (temp.) in the municipality of Cáceres - MT.

\section{Cuiabá}

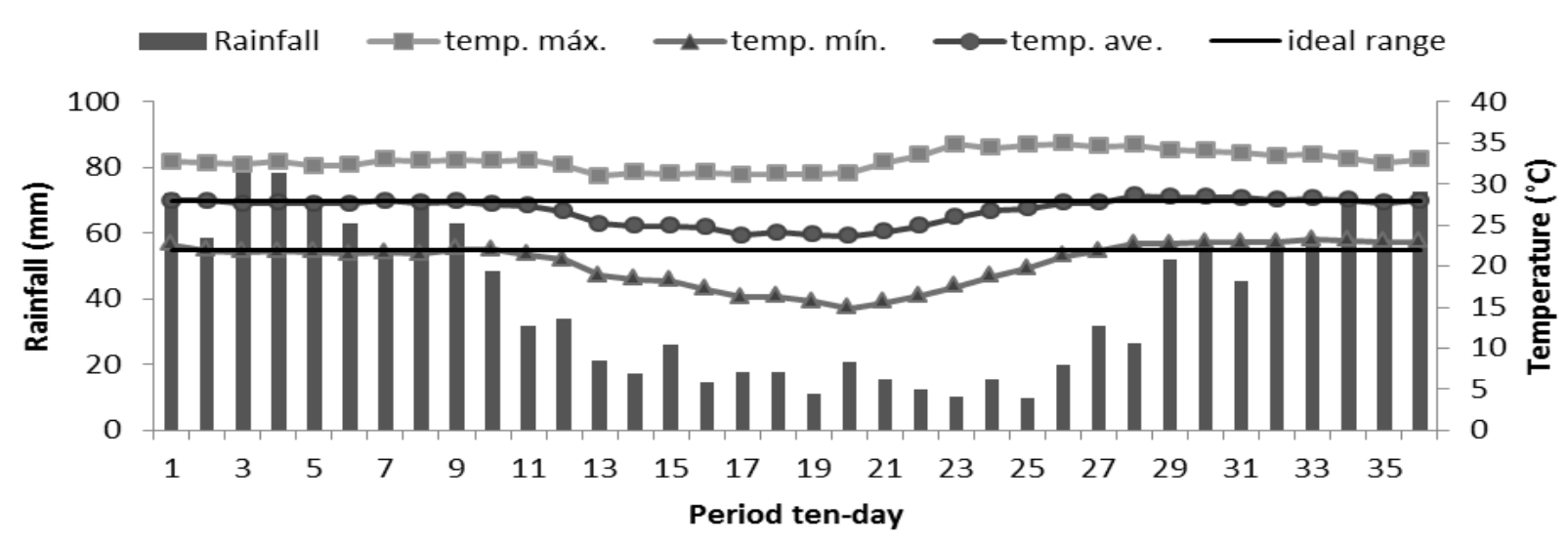

Figure 5 - Ten-day period rainfall distribution and average (ave.) maximum (máx.) and minimum (mín.) temperatures (temp.) in the municipality of Cuiabá - MT.

\section{Diamantino}

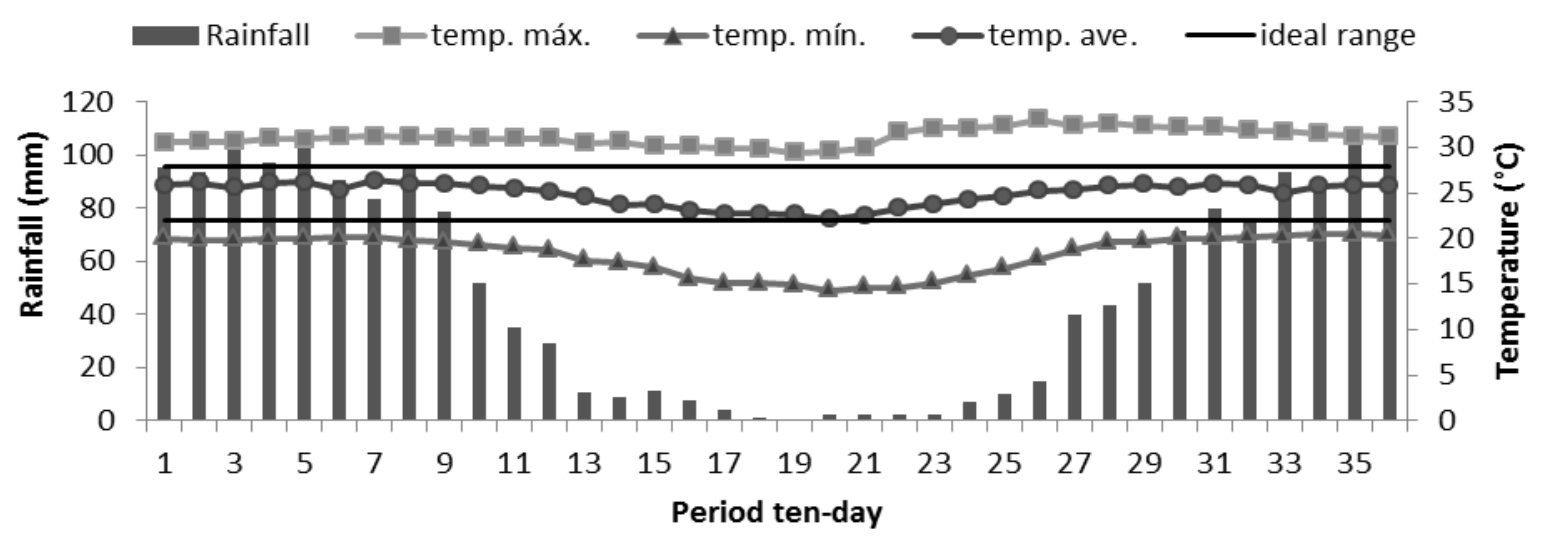

Figure 6 - Ten-day period rainfall distribution and average (ave.) maximum (máx.) and minimum (mín.) temperatures (temp.) in the municipality of Diamantino - MT. 


\section{São J. Rio Claro}

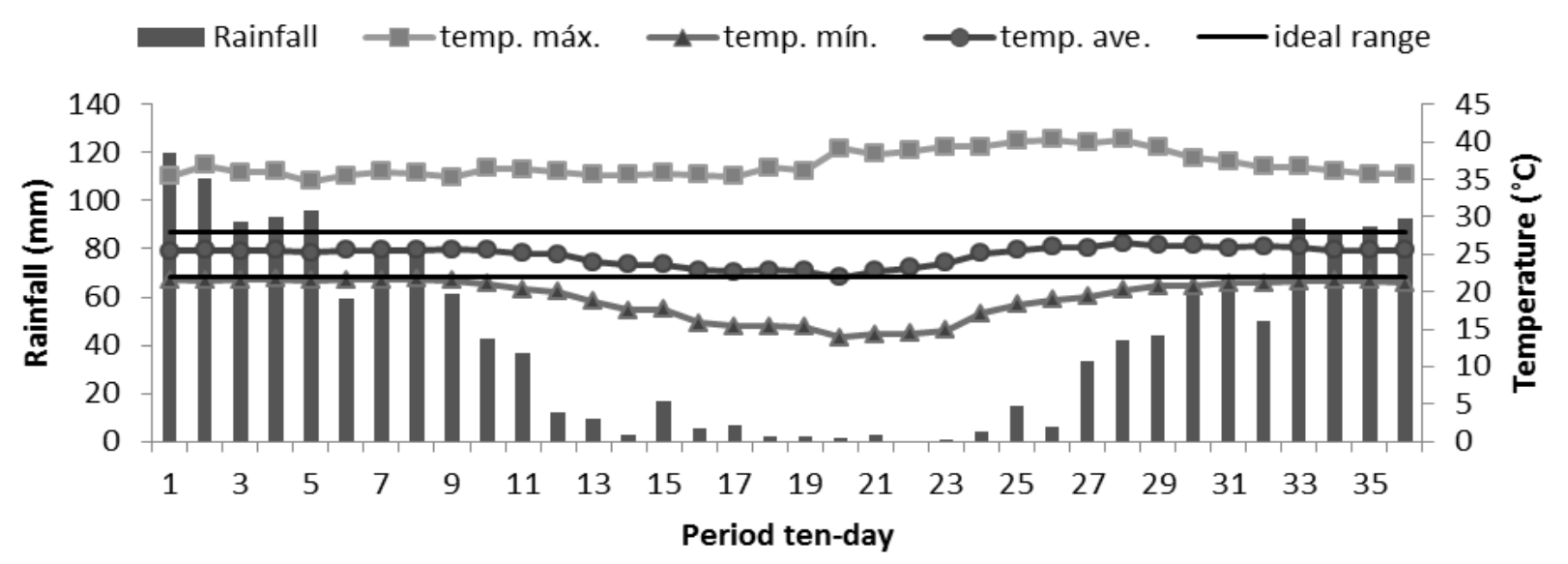

Figure 7 - Ten-day period rainfall distribution and average (ave.) maximum (máx.) and minimum (mín.) temperatures (temp.) in the municipality of São José do Rio Claro - MT.

\section{Tangará da Serra}

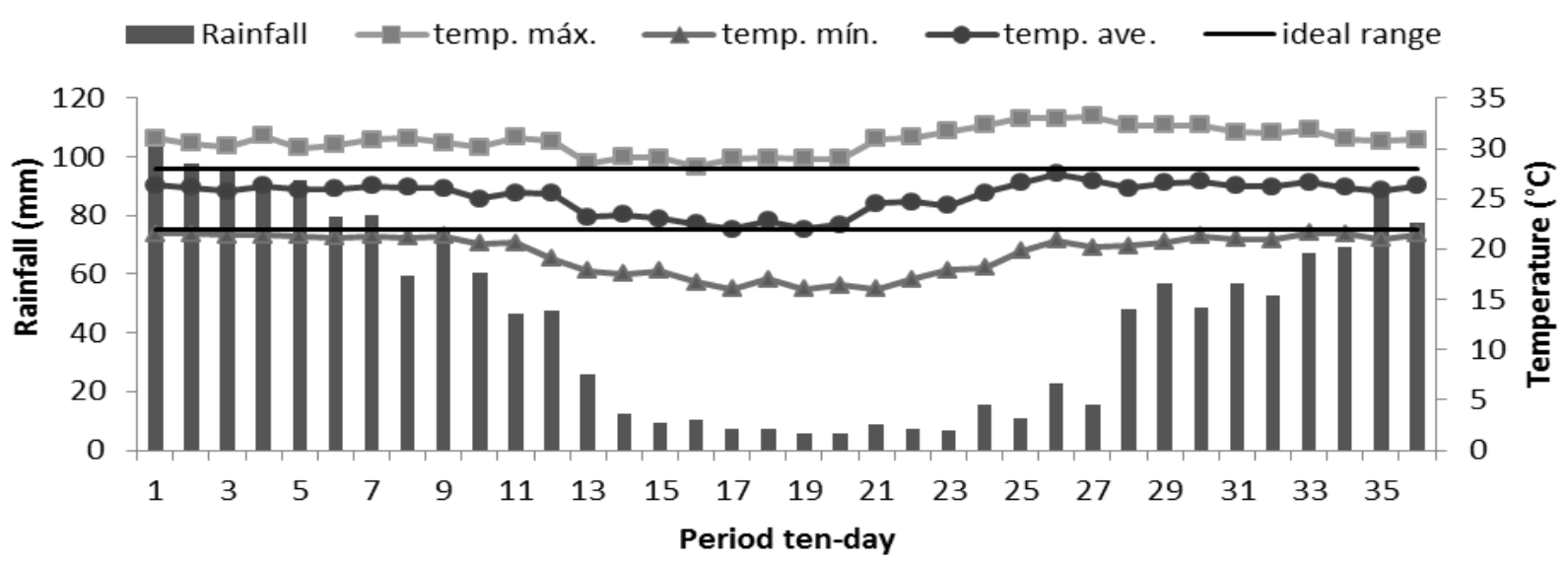

Figure 8 - Ten-day period rainfall distribution and average (ave.) maximum (máx.) and minimum (mín.) temperatures (temp.) in the municipality of Tangará da Serra - MT.

Thus, the region of Campo Novo do Parecis is characterized as being suitable for planting in periods of ten-days 34 to 5 , restricted by excessive rain in 28 to 33 ten-day period, only take into account grain moisture at harvest, which according to Silveira (2010), could cause moisture problems at harvest and inapt for water deficit in the period of 10 to 27 ten-days. Regarding thermal aptitude, the ideal range of crop cycle remains suitable for the all seasons.

For the municipality of Cáceres has a total of $1533.9 \mathrm{~mm}$ with increase from 22 to 2 ten-day and reduction of ten-day 3 to 22; in Cuiabá is observed in a total of $1493.5 \mathrm{~mm}$ where ten-day growth begins from the 26 to 36 and decreases from 1 to 16; in Diamantino with $1806.6 \mathrm{~mm}$, rainfall growth starts from 25 to 5 ten-day and decreases from 6 to 17; in São José do Rio Claro with $1614.6 \mathrm{~mm}$, the growth is from 27 to 1 , the ten-day period decreases to 14 and in Tangará da Serra with $1665.5 \mathrm{~mm}$ annual is observed growth from
23 to 1 and then it decreases from 2 until 18 of ten-days.

In the municipality of Cáceres, rain distribution during the year is more uniform than other municipalities due to the proximity to the Pantanal of Mato Grosso where rainfall occurs more frequently and with less intensity (Martins et al., 2011).

Regarding the monthly system temperature for each region (Figure 3 to 8), there are no large amplitude variation between the average of the warmest month to the coolest. In Campo Novo do Parecis, the month with the highest average temperature, is between 25 to 27 ten-day with $28.3^{\circ} \mathrm{C}$, once periods of ten-days from 16 to 20 are the coldest with an average of $21.4^{\circ} \mathrm{C}$. In other locations, such as Caceres recorded temperatures of $28{ }^{\circ} \mathrm{C}$ in periods of ten days from 30 to 33 and $22{ }^{\circ} \mathrm{C}$ in ten-days 20 ; in Cuiabá, the 23 ten-day period was the hottest, with $35^{\circ} \mathrm{C}$ and in 20 ten-day period the coolest with 
$24.3^{\circ} \mathrm{C}$. The same behavior was observed for Diamantino, with a maximum of $26.5^{\circ} \mathrm{C}$ in periods of ten days 29 to 6 and $22{ }^{\circ} \mathrm{C}$ in periods of ten-days 17 to 21. São José do Rio Claro, the 20 ten-day period had the coolest with $22^{\circ} \mathrm{C}$ and 28 ten-days period the warmer with $27^{\circ} \mathrm{C}$. For Tangará da Serra, 26 ten-days was hottest, averaging $28.5^{\circ} \mathrm{C}$, however the coolest ten-days for this location was the 17 and 19 ten-day period with average of $22^{\circ} \mathrm{C}$.

In accordance to Nogueira \& Távora (2005) the average temperature of the region in all locations, this variable remains between the levels considered ideal for peanut development.

Given the climate analyzes and comparing them to the parameters proposed by Assunção \& Escobedo (2009), it can define that the studied regions have full aptitude for peanut cultivation, since annual average temperature and rainfall are among the values considered satisfactory to the development and production of this oilseed, which suits to the planting of 34 to 5 ten-days considering an average cycle of 120 days and for the cycle end a hot and dry season to favor harvest.

\section{Conclusion}

For Tangará da Serra and the other municipalities in Western Mato Grosso, peanut cultivation can be considered suitable regarding rainfall in the period of the second crop, with sowing from December to February.

For its harvest dry and hot period is necessary, for temperature factor there was no restrictions for sowing and it could perform it at any time of year, if there is irrigation system suitable for the crop. This consideration fits for all studied regions, observing that the behavior of the regions follows the discussed by Köppen which was classified as tropical humid megathermal (Aw).

\section{Acknowledgments}

Thanks to INMET for data availability, to UNEMAT for agrometeorology laboratory, to FAPEMAT, for the financial support to the research project EDITAL UNIVERSAL/FAPEMAT - №. 009/ 2011 process $\mathrm{n}$ 749427/2011 and to Centro de Tecnologia Geoestatística (CETEGEO), by computer programs.

\section{References}

Assunção HF, Escobedo JF (2009) Estimativa da exigência hídrica do amendoim usando um modelo agrometeorológico. Irriga 14(3):325-335.

Cardozo NP, Volpe CA, Cunha AR, Sentelhas PC, Piedades SMS (2010) Temperatura base e exigências térmicas para o sub-período semeadura-emergência de duas cultivares de amendoim. Belém. Anais... XVI Congresso Brasileiro de Meteorologia.
Cunha GR, Assad ED (2001) Uma visão geral do número especial da RBA sobre zoneamento agrícola no Brasil. Revista Brasileira de Agrometeorologia 9(3):377-385.

Dallacort R, Martins JA, Inoue MH, Freitas PSL, Coletti AJ (2011) Distribuição das chuvas no município de Tangará da Serra, médio norte do estado de Mato Grosso, Brasil. Acta Scientiarum. Agronomy 33(2):193-200.

Doorenbos J, Kassam AH (1994) Efeito da água no rendimento das culturas Estudos FAO: Irrigação e Drenagem, 33. Campina Grande: UFPB, p.306

Embrapa - Empresa Brasileira de Pesquisa Agropecuária (2006) Recomendações técnicas para o cultivo do amendoim em pequenas propriedades agrícolas do Nordeste brasileiro. Campina Grande: Embrapa Algodão, 2006. (Embrapa Algodão. Circular Técnica, 102). Available at: $<$ http://sistemasdeproducao.cnptia.embrapa.br

FontesHTML/Amendoim/CultivodoAmendoim/importan cia.html> (accessed nov 10 2014).

Faria RT, Caramori PH, Chibana EY, Brito LRS Nakamura AK, Ferreira AR (2003) Clima - Programa computacional para organização e análise de dados meteorológicos. Engenharia Agrícola 23(2):372-387.

Godoy IJ, Moraes AS, Zanotto MD, Santos RC (2005) Melhoramento do amendoim. In: Borém A. Melhoramento de espécies cultivadas. Viçosa: UFV. p.54-95.

Martins JA, Dallacort R, Inoue MH, Galvanin EAS, Magnani EBZ, Oliveira K (2011) Caracterização do regime pluviométrico no arco das nascentes do rio Paraguai. Revista Brasileira de Meteorologia 26(1):639-647.

Monteiro JMG (2007) Plantio de oleaginosas por agricultores familiares do Semi-árido nordestino para produção de biodiesel como uma estratégia de mitigação e adaptação às mudanças climáticas. 302p. Universidade Federal do Rio de Janeiro Tese (Doutorado em Engenharia - Planejamento Energético).

Nogueira NJMC, Távora FJAF (2005) Ecofisiologia do amendoim. In: Santos RC. (ed.). O agronegócio do Amendoim no Brasil. Campina Grande: Embrapa Algodão, p.73.

Peixoto CP, Gonçalves JA, Peixoto MdeFdaSP, Carmo DOdo (2008) Características agronômicas e produtividade de amendoim em diferentes espaçamentos e épocas de semeadura no recôncavo baiano. Campinas: Bragantia, 67(3):673-684. 
Reichardt K (1987) O solo como reservatório de água. In: Reichardt K. A água em sistemas agrícolas. São Paulo: Manole, p.27-69.

Santos RC, Rego GM, Santos CA, Peixoto AS, Melo Filho PA, Moraes TMG, Suassuna TF (2006) Recomendações técnicas para o cultivo do amendoim em pequenas propriedades agrícolas do nordeste brasileiro. Campina Grande: EMBRAPA, 6p.

Sarr B, Lecoeur J, Clouvel P (2004) Irrigation scheduling of confectionery groundnut (Arachis hypogeaea L.) in Senegal using a simple water balance model. Agricultural Water Management 1(67):201-220.

Silva V (2008) Características fisiológicas de cultivares de mamoneira (Ricinus communis L.) no Recôncavo Baiano. 73p. Dissertação (Mestrado em Ciências Agrárias) - Centro de Ciências Agrárias e Ambientais. Universidade Federal do Recôncavo da Bahia.
Silva MT, Amaral JABdo (2008) Estimativa da evapotranspiração e coeficiente de cultivo do amendoim irrigado pelo método do balanço hídrico no solo. Revista Brasileira de agrometeorologia. 16(1):6776.

Silveira PS (2010) Época de semeadura e densidade de plantas em cultivares de amendoim no Recôncavo Sul Baiano: Amendoim - produtividade. 112 p. Dissertação (Mestrado em Ciências Agrárias) Universidade Federal do Recôncavo da Bahia.

Sousa SAV (1998) Programa computacional para simulação da ocorrência de veranicos e queda de rendimento. Pesquisa Agropecuária Brasileira 33(12):1952-1956. 